Eastern Europe

A Geography of the Comecon Countries 
Also by Roy E. H. Mellor

Geography of the USSR

Comecon: Challenge to the West 


\section{Eastern Europe}

A Geography of the Comecon Countries

Roy E. H. Mellor

University of Aberdeen 
(C) Roy E.H. Mellor 1975

Softcover reprint of the hardcover 1st edition 1975

All rights reserved. No part of this publication may be reproduced or transmitted, in any form

or by any means, without permission

First published 1975 by

THE MACMILLAN PRESS LTD

London and Basingstoke

Associated companies in New York Dublin

Melbourne Johannesburg and Madras

ISBN 978-0-333-17311-4 ISBN 978-1-349-15559-0 (eBook)

DOI 10.1007/978-1-349-15559-0

The paperback edition of this book is sold subject to the condition that it shall not by way of trade or otherwise, be lent, resold, hired out, or otherwise circulated without the publisher's prior consent in any form of binding or cover other than that in which it is published and without a similar condition including this condition being imposed on the subsequent purchaser. 


\section{Contents}

List of Illustrations vii

List of Tables viii

Preface ix

PART ONE: PHYSICAL ENVIRONMENT AND POLITICAL GEOGRAPHY

1. The Physical Environment 3

1.1 Definitions of Eastern Europe 3

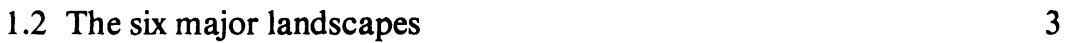

$\begin{array}{lr}1.3 \text { Structure } & 6\end{array}$

$\begin{array}{ll}1.4 \text { Climate } & 23\end{array}$

$\begin{array}{ll}1.5 \text { Soils } & 28\end{array}$

1.6 Vegetation of flora 31

$\begin{array}{ll}1.7 \text { Fauna } & 33\end{array}$

2. Historical Evolution from the Graeco-Roman Period to the Early Twentieth Century $\quad 35$

2.1 Early times $\quad 35$

2.2 Europe of the dynastic empires: late tenth century to 1918

3. Historical Development in the Twentieth Century 65

3.1 The new Europe, 1918-45 65

3.2 An even newer Europe: Aftermath of the Second World War 83

PART TWO: THE DEMOGRAPHIC AND ECONOMIC

FRAMEWORK 95

4. Population $\quad 97$

4.1 Distribution of population $\quad 97$

$\begin{array}{ll}4.2 \text { Population growth } & 104\end{array}$

4.3 Age and sex composition 113

$\begin{array}{ll}4.4 \text { Migration } & 116\end{array}$

$\begin{array}{ll}4.5 \text { The ethnic quilt } & 123\end{array}$

5. Town and Village 136

5.1 Town: A general survey 136

5.2 Examples of selected towns $\quad 142$

5.3 Villages: A general survey 162

5.4 The impact of socialisation on the village 168 
6. The Economic Landscape before the Second World War 170

$\begin{array}{ll}6.1 \text { Agriculture } & 171\end{array}$

6.2 The development of industry before $1945 \quad 185$

6.3 Industrial geography between the two world wars 190

$\begin{array}{ll}\text { 7. Transport } & 197\end{array}$

7.1 Roman and medieval transport systems $\quad 197$

$\begin{array}{ll}7.2 \text { Roads } & 198\end{array}$

7.3 Waterways since Napoleonic times $\quad 202$

$\begin{array}{ll}7.4 \text { Railways } & 207\end{array}$

$\begin{array}{ll}7.5 \text { Ports and shipping } & 216\end{array}$

$\begin{array}{ll}7.6 \text { Airways } & 216\end{array}$

PART THREE: COMECON AND THE NATIONAL

$\begin{array}{ll}\text { ECONOMIES } & 219\end{array}$

8. The Genesis of Comecon and the Sovietisation of Eastern Europe 221

8.1 The origins and development of Comecon 222

8.2 The Sovietisation of Eastern Europe 234

8.3 The international socialist division of labour 239

9. Sketches of National Economic Geographies: the Developed Countries

9.1 German Democratic Republic 249

$\begin{array}{ll}9.2 \text { Poland } & 261\end{array}$

$\begin{array}{ll}9.3 \text { Czechoslovakia } & 273\end{array}$

9.4 Hungary 284

10. Sketches of National Economic Geographies: the Developing Countries

$\begin{array}{ll}10.1 \text { Rumania } & 295\end{array}$

$\begin{array}{ll}10.2 \text { Bulgaria } & 306\end{array}$

$\begin{array}{ll}10.3 \text { Jugoslavia } & 314\end{array}$

$\begin{array}{ll}10.4 \text { Albania } & 325\end{array}$

Alternative Names for the Principal Places 328

Bibliography $\quad 335$

$\begin{array}{ll}\text { Index } & 349\end{array}$ 


\section{List of Illustrations}

Figure 1.1 Relief with regional and feature names

Figure 1.2 Climate 24

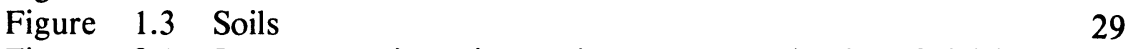

Figure 2.1 Roman Empire at its maximum extent, with line of division and boundaries between East and West 36

Figure 2.2 Four small maps of Eastern Europe (a) $1000 \mathrm{AD}$; (b) 13th century; $(c)$ 14th century; $(d)$ 16th century 38

Figure 2.3 Ethnicity c. 100 AD with migration of Slavs 41

$\begin{array}{lll}\text { Figure } 2.4 \text { Expansion of German settlements } & 45\end{array}$

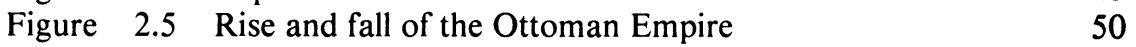

$\begin{array}{lll}\text { Figure } & 2.6 \text { Slav migration in Turkish times } & 51\end{array}$

Figure 2.7 Habsburg domains, 1526-1918 53

$\begin{array}{lll}\text { Figure } & 2.8 \text { Eastern Europe from the 18th century to the present day } \quad 57\end{array}$

$\begin{array}{lll}\text { Figure } 2.9 & \text { Balkans 1815-1915 } & 61\end{array}$

$\begin{array}{llll}\text { Figure } & 3: 1 & \text { Partitions of Poland } & 68\end{array}$

$\begin{array}{lll}\text { Figure } 3.2 \text { Growth of Poland } & 70\end{array}$

$\begin{array}{lll}\text { Figure } & 3.3 \text { GDR - Länder and Bezirke } & 90\end{array}$

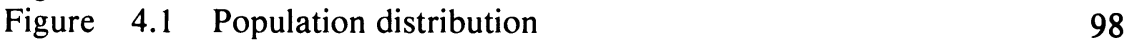

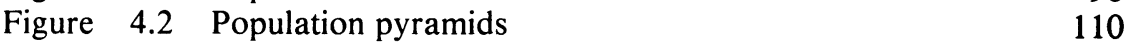

$\begin{array}{lll}\text { Figure } 4.3 \text { German refugees } & 119\end{array}$

$\begin{array}{llll}\text { Figure } 4.4 & \text { Ethnic distribution: } 1910 \text { and } 1950 & 124\end{array}$

$\begin{array}{lll}\text { Figure } 5.1 \text { Distribution of towns by size } & 140\end{array}$

$\begin{array}{lll}\text { Figure } & 5.2 \text { Old Berlin } & 143\end{array}$

$\begin{array}{lll}\text { Figure } & 5.3 \text { Modern Berlin } & 146\end{array}$

$\begin{array}{llll}\text { Figure } & 5.4 & \text { Old Prague } & 149\end{array}$

$\begin{array}{lll}\text { Figure } & 5.5 \text { Modern Prague } & 151\end{array}$

$\begin{array}{lll}\text { Figure } & 5.6 \text { Old and modern Warsaw } & 152\end{array}$

$\begin{array}{lll}\text { Figure } & 5.7 \text { Modern Budapest } & 155\end{array}$

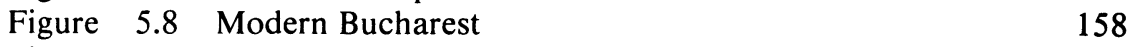

$\begin{array}{lll}\text { Figure } & 5.9 \text { Modern Belgrade } & 160\end{array}$

$\begin{array}{ll}\text { Figure } 5.10 \text { Types of villages } & 163\end{array}$

$\begin{array}{lll}\text { Figure } & 5.11 \text { Examples of villages } & 164\end{array}$

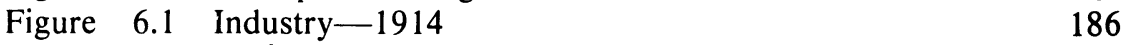

$\begin{array}{lll}\text { Figure } 7.1 \text { Waterways and ports } & 206\end{array}$

$\begin{array}{llll}\text { Figure } 7.2 & \text { Railways up to } 1918 & 210\end{array}$

$\begin{array}{lll}\text { Figure } 7.3 \text { Railways since } 1918 \text { and major highways } & 211\end{array}$

$\begin{array}{lll}\text { Figure } & \text { 8.1 Examples of collectives } & 241\end{array}$

$\begin{array}{lll}\text { Figure 9.1. Industry in the GDR } & 251\end{array}$

$\begin{array}{lll}\text { Figure } 9.2 \text { Agriculture in the GDR } & 258\end{array}$

$\begin{array}{lll}\text { Figure 9.3. Industry in Poland } & 264\end{array}$

$\begin{array}{llll}\text { Figure } 9.4 & \text { Agriculture in Poland } & 269\end{array}$

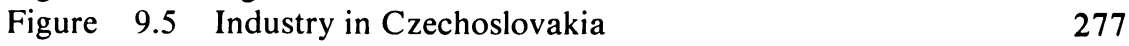




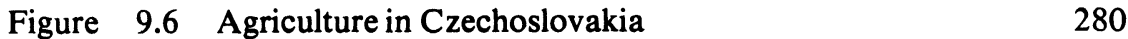

Figure 9.7 Industry in Hungary 286

$\begin{array}{lll}\text { Figure } & 9.8 \text { Agriculture in Hungary } & 290\end{array}$

$\begin{array}{lll}\text { Figure } 10.1 & \text { Industry in Rumania } & 298\end{array}$

$\begin{array}{lll}\text { Figure } 10.2 & \text { Agriculture in Rumania } & 302\end{array}$

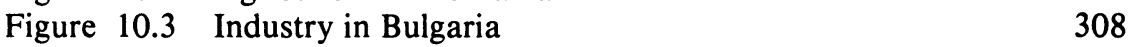

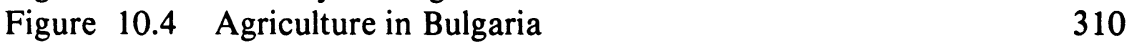

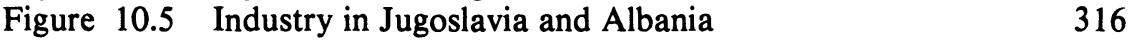

$\begin{array}{lll}\text { Figure } 10.6 & \text { Agriculture in Jugoslavia } & 320\end{array}$

\section{List of Tables}

Table 1.1 Climatic data for selected stations 26

Table 4.1 Eastern Europe-population 1850-2000 AD 105

Table 4.2 Growth of population in Eastern Europe 106

Table 4.3 Population and territorial change in Rumania 109

Table 4.4 Population in post-1945 area of Jugoslavia 112

Table 4.5 Annual natural population increase in Albania 112

Table 4.6 Life expectancy in mid-1960s_age in years 113

Table 4.7 Age structure in the German Democratic Republic 114

Table 4.8 Ethnic composition of Eastern Europe c. 1930-9 121

Table 4.9 Ethnic composition of Eastern Europe c. $1960 \quad 122$

$\begin{array}{lll}\text { Table 5.1 Population of Berlin 1740-1970 } & 148\end{array}$

Table 5.2 Population of Warsaw 1860-1970 154

Table 5.3 Population of Budapest 1830-1970 156

Table 5.4 Population of Bucharest 1831-1970 159 


\section{Preface}

The copious geographical literature on the Soviet Union in the English language is unmatched by material for the Socialist states of Eastern Europe, which remain relatively little known to English-speaking students. At the present pace of change in Europe, it would be a pity to concentrate our interest on Western Europe and omit to examine the remarkable developments taking place in the other half of Europe. The language problem has certainly been a barrier for most interested people and few of us are fortunate enough to have access to Magyar, Rumanian and the several Slav languages, let alone to Albanian and German. This is unfortunate, because several of the countries have a long, respectable if little known tradition of geographical study and have produced a valuable literature in their own vernaculars. This book has sought in particular to draw on this excellent if relatively inaccessible source material.

For reasons of length it has been decided not to expand on the physical background other than to set a backcloth for the study, and the work is primarily concerned with the complex and diverse human geography. Particular attention has been paid to the historical background, especially in the past two hundred years, since it is felt that the great changes arising from the acceptance of a Marxist-Leninist order of society and economy in the last twenty-five years can only be fully appreciated if seen in their historical setting. Stemming from this approach, the reader may sense the emphasis on the political-geographical pattern, but he will well appreciate that in this part of Europe, with the upheavals of centuries, political geography is a spectre that has to be lived with. Indeed the contemporary scene cannot be adequately interpreted without an understanding of what has gone before. Even a quarter of a century of the rigorous impress of Marxist-Leninism and the more recent changes that have begun to emerge from Comecon cannot conceal the imprint, remarkably fresh inspite of events, left by the great empires that confronted each other in a relentless power struggle over this part of Europe. Attention has also been given to the way in which Sovietisation and the interpretation of Marxist-Leninist dogmas have been remoulding the visible landscape, an aspect of political geography too long given little consideration.

The study of an area so diverse and complex as Eastern Europe presents numerous methodological and interpretive challenges. An initial challenge is to find a thread of identity for the study to make it, some would claim, regionally respectable. This thread seems to be presented by the apparent unity created by the acceptance of Soviet-style Marxist-Leninism and its imposition on divergent ethnic and economic backcloths. In a sense, a new region-Eastern Europe of the eight Socialist states-has emerged from what were previously a part of Central Europe (in itself an elusive concept), and the Balkans, sometimes more generously defined spatially as South-eastern Europe, besides the true eastern marchlands of Europe that lap into the Soviet Union. With eight countries at different levels of social and economic development and possessing sub- 
stantial organisational divergences, the treatment must naturally be a little uneven, but every attempt has been made to give a reasonably equal coverage of each country in relation to its size and diversity and its role in the area's affairs. The deficiencies are most apparent in the statistical material, both on a comparative scale between countries and over time, especially for those countries that have undergone violent territorial change.

The work owes much to many helpful people in Eastern Europe, too numerous to name. I might, however, mention especially Professor Dušan Brkić of Sarajevo whose wide conceptual view of the problems of Europe's Socialist states has been a long-standing inspiration. Dorota and Manfred Alexander of the University of Cologne have combed Eastern Europe's bookshops for me. For my own travels I owe a grateful acknowledgement of help received from the Carnegie Trust for Scotland. Much laborious compilation was done by my assistant, Miss Sheila Bain, while the maps were produced by Laurie McLean and Bert Bremner, the quality of whose work will be readily appreciated. The manuscript was typed by Mrs I. J. Greig, who mastered with incredible success the eccentricities to the British eye of Slav and Magyar spelling. Whenever my spirit has flagged I have been grateful for the encouragement received from colleagues, particularly Kenneth Walton and Alistair Smith. The latter along with Chalmers Clapperton gave noble help in reading a remarkably illegible series of drafts. Much of the original encouragement came from my wife, whose intimate knowledge of the Slav lands, their peoples and languages, has been invaluable. She has also done so much of the drearier tasks of reading manuscripts and checking text, besides using her culinary skills without which no energyconsuming author can survive. For errors, slips and deficiencies, I alone am responsible.

Roy E. H. Mellor 